\title{
Evaluation of Selected Internship Factors on Mastery of Soft Skills among Interns: Evidence from Nakuru County Government, Kenya
}

\author{
Changwony Jepkorir Purity, Dr. Maina Waiganjo, Dr.Simon Kipchumba
}

\begin{abstract}
This study aimed to evaluate selected internship factors on mastery of soft skills among interns in the County Government of Nakuru. The specific objectives of the study are to analyse the effect of assessment criteria, competency of internship supervisors, person role fitness and institutional support on soft skills mastery among interns in Nakuru County Government. The studywas anchored on experiential learning theory and Dreyfus model. The study adopted a descriptive research design. The population of the study was the $\mathbf{1 3 0 0}$ interns stationed in the Nakuru County Government during the month of August from which a sample of 102 interns was obtained using stratified random sampling technique and a structured self-administered questionnaire was used to collect data. A pilot study was conducted in Baringo County, Mogotio Sub-county to ascertain the validity and reliability of the research instrument. Statistical Package for Social Sciences (SPSS) was used to analyze the data to obtain both descriptive and inferential statistics. The main descriptive statistics obtain were frequencies, percentages, means and standard deviation. Inferential statistics employed were Pearson's product moment correlation which helped to compute the direction and strength of the linear associations. Simple and multiple regression analysis were used to test the association between the variables. The study found out that assessment criteria significantly $(\beta=0.772$, Sig. $<0.05)$ affected soft skills mastery among interns in Nakuru County Government. The study also found out that Institutional Support significantly $(\beta=0.811$, Sig. $<0.05)$ affected soft skills mastery among interns in Nakuru County Government. This study further found out that person role fitness significantly $(\beta=1.139$, Sig. $<0.05)$ affected soft skills mastery in Nakuru County Government. However, the study found outthat there is no statistically significant $(<0.05)$ effect of competence of the internship supervisors on soft skills mastery among the interns in Nakuru County Government. Thus, it was concluded that assessment criteria, person role fitness and institutional support were significant factors of internship which affect soft skills mastery among interns in the County. The study recommends that college institutions should work in collaboration with the organizations or industries where the students are sent for their internship programs to ensure that there is a good assessment criteria put in place, that the interns are well placed as per their professions (person role fitness) and ensure institutional support in order to enhance soft skills mastery among the interns as evidenced from Nakuru County Government, Kenya.
\end{abstract}

Changwony Jepkorir Purity, Kabarak University - School Of Business and Economics, Kenya

Dr. Maina Waiganjo, Kabarak University - School Of Business and Economics, Kenya

Dr.Simon Kipchumba, Kabarak University - School Of Business and Economics, Kenya
Index Terms - Internship Factors, Internship, Assessment Criteria, Competence, Institutional support, Person role fitness, Soft skills Mastery.

\section{INTRODUCTION}

Human resource is the most important resource of an organization (Negruta, 2015). The competence of this resource in a workplace is partly dependent on the training they possess both the hard and soft skills are critical. Hard skills are taught in a classroom set up while internship plays a crucial role in the mastery of the soft skills. Internships are programs that engage students in tasks mainly with the determination of providing them with the necessary experience that enhances their education and mastering of soft skills and hard skills to a professional area of study (Bukaliya, 2012).

Internship involve a limited period of work experience with an employer usually lasting between a few weeks to one year (in some rare cases even longer) but which is neither part of a regular employment relationship nor a formal apprenticeship (Meeks, 2017). It also serves as excellent training ground for developing the necessary "professional skills", which are necessary for the future job (Negruta, 2015). It must be noted by both the host and the institutions that internships factors are the key aspects of an effective internship program. According to Wen (2010), organizational factors (Assessment criteria, person role fitness, competence of the internship supervisors and institutional support) are the important ingredients of an effective internship hence justifying the selection of the internship factors by the researcher in the current study.

Maximum support is needed from both the institution and the mentors in terms of space, equipment, expert's time, potential training and travel costs, among other costs. The university will have to devote resources to set up and maintenance of relationships with host organizations. Having a competent supervisor for internships would be very beneficial. The institution must also constantly determine the quality of implementing the internship and changes that need to be made to enhance the student's mastery of soft skills. "Soft skills are also referred as emotional intelligence, soft skills mastery contributes more to an individual's ultimate success or failure than technical skills or intelligence," (Goleman, 2011). The Protocol School of Washington, DC and conducted by Harvard University, the Carnegie Foundation and the Stanford Research Institute has shown that technical skills and knowledge account for about 15 
percent of the reason an individual gets a job, keeps the job and advances in that job, the remaining 85 percent of job success is based on the individual's "soft skills" (Crosbie, 2005).

\section{A. Statement of the Problem}

The curriculum that most college graduates are exposed to largely offer hard skills, but important soft skills that would make them well prepared for work environment are lacking. The deficiency of these soft skills among the interns create problems in their future at work place since today's work environment require highly developed soft skills due to the flattening of the organizational structure. Employers are concerned with the level and relevance of a broad set of soft skills amongst entry level workers and there is an increasing demand on new college graduates to have a mastery of soft skills in order for them to be ready to enter the work environment. An internship is often the first interaction with work environment for a student, and may be the best opportunity for soft skill mastery. Literature support that soft skills should not be overlooked and it should accompany hard skills (Agarwal et al., 2018). And this study seeks to investigate the mastery of teamwork, problem solving skills, critical thinking skills, and communication skills determined by the selected internship factors (assessment criteria, competence of internship supervisors, person role fitness and institutional support). Nakuru County Government value soft skills mastery when recruiting new graduates and human resource managers are keen on testing these soft skills during interviews. In addition, this institution is unique in the sense that it offers many opportunities to interns not only for acquiring workplace functional experience but also learn and master soft skills for a minimum period of three months. The studies that have been done in Nakuru County and other counties in Kenya largely focus on other attributes example, a study by Waiganjo and Waiganjo (2018) examined the relevance of life skills education in preparing Kenyan youth for national development. A study conducted by Yanawati (2017) examined the need for implementing soft skills workshop that could be an instrumental in developing and improving soft skills. Study by Mayaka and King (2002) examined the soft skills needed by Kenya's tour-operating sector and the extent to which current training provision is adequate. None of these studies addressed the concerns of the present study therefore this study seeks to close this gap by evaluation of the selected internship factors on mastery of soft skills among the interns, evidence from of Nakuru County Government.

\section{B. Objectives of the Study}

i. To assess the effect of assessment criteria on soft skills mastery among interns in Nakuru County Government.

ii. To examine the effect of competency of the internship supervisors on soft skills mastery among interns in Nakuru County Government.

\section{Research Hypotheses}

$\mathrm{H}_{0} 1$ : There is no statistically significant effect of assessment criteria on soft skills mastery in Nakuru County Government.
$\mathrm{H}_{0} 2$ : There is no statistically significant effect of competence of the internship Supervisors on soft skills mastery in Nakuru County Government.

\section{LITERATURE REVIEW}

\subsection{Theoretical Review}

Theories are formulated to explain, predict, and understand phenomena and, in many cases, to challenge and extend existing knowledge within the limits of critical bounding assumptions (Ngulube, Mathipa\& Gumbo 2015). The theoretical framework is the structure that can hold or support a theory of a research study. The theoretical framework introduces and describes the theory that explains why the research problem under study exists (de Lima, 2017).

\subsubsection{Dreyfus Model of Skill Acquisition}

Dreyfus and Dreyfus (1980) came up with a five-stage model of the mental activities involved in directed skill acquisition and discussed each skill level in great detail. The basic content of the Dreyfus model is that students' progress through five stages of expert status in this specific order: novice, advanced beginner, competent, proficient, and expert. The researchers found out that novices adhere to the set rules. Novices do not think critically nor do they exercise discretionary judgment. Advanced beginners on the other hand take a more holistic approach to the problem at hand than the novices, but advanced beginners have a limited understanding of the problem. Competency is achieved when one start to plan his work and create routines and structure the work. Proficiency is achieved when one prioritizes different elements of the work the researchers suggested that one can know that he/she has reached proficiency when they truly grasp the whole of what one is trying to achieve. Finally, they concluded that, experts possess an intuitive grasp of situations based on deep, tacit understanding. Experts forego rules. Instead, they make decisions based on analytical approaches.

Students move through the five stages of expert status or similar processes as they participate in internships, reflect on the experience throughout the program, and measure how the experience enhance soft skills mastery. Given their active engagement in internship, interns may be more likely to master soft skills and move forward into being expert with new ideas and motivation to explore the world. The model however is limited to the five stages of expert status other than considering other aspects that influence learning. Hence the researcher incorporated experiential learning theory to support the aforementioned model.

\subsubsection{Experiential Learning}

John Dewey laid significant groundwork for the theory in his book, 'Experience and Education' (Dewey, 1938). Dewey stressed the importance of experience in education; he noted that there is an intimate and necessary relation between the experience and education (Dewey, 1938). According to his study experience is always a dynamic two-way process involving both trying and undergoing. He referred to this process as a transaction taking place between the individual and what at the time constitutes the environment doing is the purposeful engagement of the individual with the environment in Dewey's words doing is an attempt made to 
have an impact on the world. 'Undergoing' on the other hand refers to the consequences of the experience for us.

"Education must be conceived as a continuing reconstruction of experience, the process and goal of education is one and the same thing" (Dewey, 1938). Dewey $(1997,2011)$ encouraged learners to have a direct interaction with the phenomena being studied, including purposeful reflection, which allows students to synthesize and internalize the direct experience. Dewey believed that education is meant to help the learner think deeply through habitual reflection (Dewey, 1997, 2011). Dewey encouraged the active learner to consider how their beliefs shape their actions. As the learner reflects on what he or she knows, it can influence their next interaction, decision, and potential growth.

Building upon earlier work by Dewey, Kolb believes "learning is the process whereby knowledge is created through the transformation of experience" (Kolb, 1984). Kolb suggests that previous experiences, hereditary characteristics, and current environment together drive development of a preferred way of grasping and processing experiences. The combination of these preferred methods contributes to specific learning styles, such as initiating, experiencing, imagining, reflecting, analyzing, thinking, deciding, acting and balancing. Students' learning styles have been assessed by using the learning style inventory (Kolb\& Kolb 2005).

Students engaged in internships are adapting to the work environment as a learning place versus classroom. Students move through the experiential learning cycle or similar processes as they participate in internships, reflect on the experience throughout the program, and measure how the experience enhance soft skills mastery. Students are challenged to think about their daily internship experiences and resolve internal and external issues they are confronting at the real working environment. However, according to Kolb effective learning only occurs when a learner can execute all four stages of the model.

\subsection{Empirical Review}

The empirical studies that have been conducted in the past five years in respect to selected factors of internship are reviewed. These studies are examined in light of soft skills mastery among interns.

\subsubsection{Assessment Criteria and Mastery Soft Skills}

According to Brookhart (2018) assessment criteria are descriptive statements that give learners and instructors the information about the characteristics, aspects and qualities of a given learning activity making clear to the learners what they are expected to do for them to achieve their goals and the instructors will consider when making judgments about their achievements.

A study by Alem and Boudreau (2012) in the University of Southern California on the criteria to measure the performance of student interns before, during, and after their internships as well as criteria to measure their overall performance was included in the grid. The ultimate objective of the creation of this grid was to provide a validated assessment grid to the university supervisors responsible for internship placements and the internship supervisors to better assess the interns on soft skills mastery. The authors came up with the following four metric qualities to analyze those criteria: their degree of difficulty, their degree of discrimination, their degree of internal consistency and their concurrent validity. According to the findings it was noted that it is important to sensitize professional supervisors and student interns to take advantage of the full range of the evaluation scale to enhance soft skills mastery of the interns.

According to Nusrat (2018), a study conducted in Bangladesh, whose main objective was to identify the most desired soft skills frequently sought by employers for potential candidates to attain and sustain employment for graduate, about two million new faces are joining the workforce annually; but two-thirds of them remain unemployed or underemployed. On the other hand, industries in Bangladesh are running with 10-15 percent vacant positions, problem of employability occurs due to the lack of soft skills in the entry-level graduates due to poor assessment criteria employed during the internships.

The study was conducted by Washor (2015), to examine the degree to which internships assessment criteria enhance student soft-skill mastery, specifically in the areas of communication, teamwork, initiative, and, analytical thinking. Researcher designed pre-post retrospective surveys were given to the interns and another one to corresponding supervisors to measure change in soft-skill development during a 13-week semester as a direct result from participating in an internship. It was found out that 278 students $(88 \%)$ and 287 supervisors $(91 \%)$ consented to participate in the study and completed all of the items on the survey regarding soft-skill development. It was found that using good internship assessment criteria contributes to student soft-skill mastery. However, the study did not research in depth the effects of internship factors which are Quality implementation on soft skills mastery.

A study conducted by Yanawati (2017) examined the need for implementing assessment criteria that could be helpful in acquiring and enhancing soft skills program in UMP. The UMP Soft skills components consist of problem solving, leadership, team working, oral communication, written communication, and learning capabilities. Hence, the soft skills expert group at the Centre for modern languages and human sciences, UMP took the initiative in organizing the soft skills workshop for final year students before they went for their internship. The main objective was to unveil the awareness of employability skills and market requirements that should be mastered by interns.

Throughout the sessions, which based on the modules, group activities and assessments criteria, the workshop aim was to instill and nurture the soft skills components within the students. A total of 226 final year Engineering students out of 549 were selected as respondents. The study was conducted using survey methods. The descriptive methods of statistical data analysis were utilized. Based on the analysis of the findings, generally it was found that the majority of the respondents agreed to the assessment criteria of the soft skills workshop. Most of them (more than 50\%) stated that the "strongly agree" and "agree" results to all question asked. The study however agreed with the implementation process of soft skill mastery but did not show the correlation between 


\section{Evaluation of Selected Internship Factorson Mastery of Soft Skills among Interns: Evidence from Nakuru County}

Government, Kenya

internship and soft skills mastery.

The most crucial prerequisites for successful implementation of internship is the need for careful consideration of the assessment criteria or how learning takes place during internship (Govindasamy, 2001). In practice, however, this is often the most neglected aspect in any effort to effectively implement internship programs through teaching and learning activities. Internships are supervised work experiences whereby students leave their institutions and get engaged in work related programmes, during which period they are closely supervised by experienced job incumbents (Bukaliya, 2012).

Internships are considered a valuable learning experience by students, academics and prospective employers (Mgaya, 2014). Internships have been hailed for integrating classroom education with internship programs in enabling students to develop their professional knowledge and essential soft skills (Bukaliya, 2012). Integration of teaching and learning in schools in the activities of industry practice will eliminate the difference of standard grades in school, in industry, and simultaneously bring supply and demand of labor. Through the cooperation, it can be obtained an optimum outcome and output that are the creation of qualified human resources (HR) in accordance with the needs of society and the labor market (Clokie\&Fourie, 2016).

\subsubsection{Competency of the Internship Supervisors and} Mastery of Soft Skills

Competency is the ability to perform well in a specific job role (Lasse,2015). Competency of the internship supervisors is essential for improving hard and non-technical skills of graduates who are the potential employees (Mgaya, 2014). Currently, higher institutions are aiming at improving their field attachments in an environment of world-wide economic stagnation which has seen many companies taking a variety of measures such as scaling back their expansion plans, reducing their operations, or even closing their businesses (Mgaya, 2014).

A study conducted by Gloria, Hird\& Tao (2008) assessed the self-reported supervision practices, experiences, and multicultural competence of white intern supervisors $(n=$ 211). White training directors and staff psychologists who were currently supervising predoctoral interns completed a 2-page survey regarding their multicultural supervision. Female supervisors reported higher multicultural supervision competence and spent more time processing cultural differences with their supervisees than male supervisors. Training directors also reported higher multicultural supervision competence than staff psychologists. Further, the number of interns supervised currently and over a career significantly predicted multicultural supervision competence. Recommendations for White intern supervisors include ongoing participation in education and professional practice experiences to improve multicultural supervision competence.

According study conducted by Hannon (2000), on national medical education needs' assessment of interns and the development of an intern education and training program, a needs' assessment of interns was undertaken using a self-completion questionnaire and a semi structured interview. A 25\% random sample of 1996 graduate doctors were selected from the five medical schools in Ireland $(n=95)$. The overall response rate was $88 \%(n=84)$. Of the responders, $91 \%$ reported that they were not prepared for all the soft skills needed as an intern. The findings History taking and clinical examination were considered well covered at the undergraduate level but little training was received in a range of professional competencies and soft skills. Although the recommendation of the study was to improve internship, it did not clearly show the link between the competence and soft skills mastery.

In Malaysia, the higher education institutions have realized that in order to produce first class human capital requires a new alternative to increase the level of thinking as well as mastery of soft skills in a dynamic self by the passage of time (Mohammed, 2017). Internships are supervised work experiences whereby students leave their institutions and get engaged in work related programmes, during which period they are closely supervised by experienced job incumbents (Bukaliya, 2012).

The importance of developing soft skills mastery among students should be the top in the list of all the Higher Educational Institutions (HEIs) so as to ensure that students are well prepared to join the workforce. Therefore, it is essential for HEIs to distinguish the knowledge and soft skill levels of their students so that strategies and intervention could be implemented to improve their capabilities. Hence, it is vital that continuity between the stakeholders and the professional development of students is present in institutions. To improve learning in higher education, internship is very vital (Mgaya, 2014).

A study conducted by Walo (2000) focused on three main objectives which were; to identify the management competencies that managers of organizations within tourism and hospitality industries expected of recent tourism and hospitality graduates; to determine whether students' management competencies were developed during the internship component of Southern Cross University's Bachelor of Business in Tourism degree; and to determine whether the management competencies of Southern Cross University's Bachelor of Business in Tourism students met the expectations of selected managers of organizations in four tourism and hospitality sectors. The study utilized the 24 management competencies and eight roles of Quinn, Thompson, and Competing Values Framework (CVF) to test two research hypotheses. The first hypothesis proposed that students' pre-internship mean scores would be significantly lower than their post-internship mean scores with respect to the 24 management competencies and eight managerial roles associated with Competing Values Framework.

The second hypothesis proposed that students' post-internship mean scores would not be significantly lower than the selected managers' mean scores with respect to the 24 management competencies and eight managerial roles associated with Competing Values Framework. A specific survey instrument, the Self-Assessment of Managerial Skills, was used to survey managers the study found generic management competencies should be effectively equipped to undertake a range of managerial opportunities that may be 
presented to them. However, the study did not evaluate selected internship factors on soft skills mastery thus the need for further research in this area.

\subsection{Conceptual Framework}

A conceptual framework is a set of broad ideas and principles taken from relevant fields of inquiry and used to structure a subsequent presentation (Paul, 2011). It can also be viewed as an end result of bringing together a number of related concepts to explain or predict a given event, or give a broader understanding of the phenomenon of interest - or simply, of a research problem (Imenda, 2014),

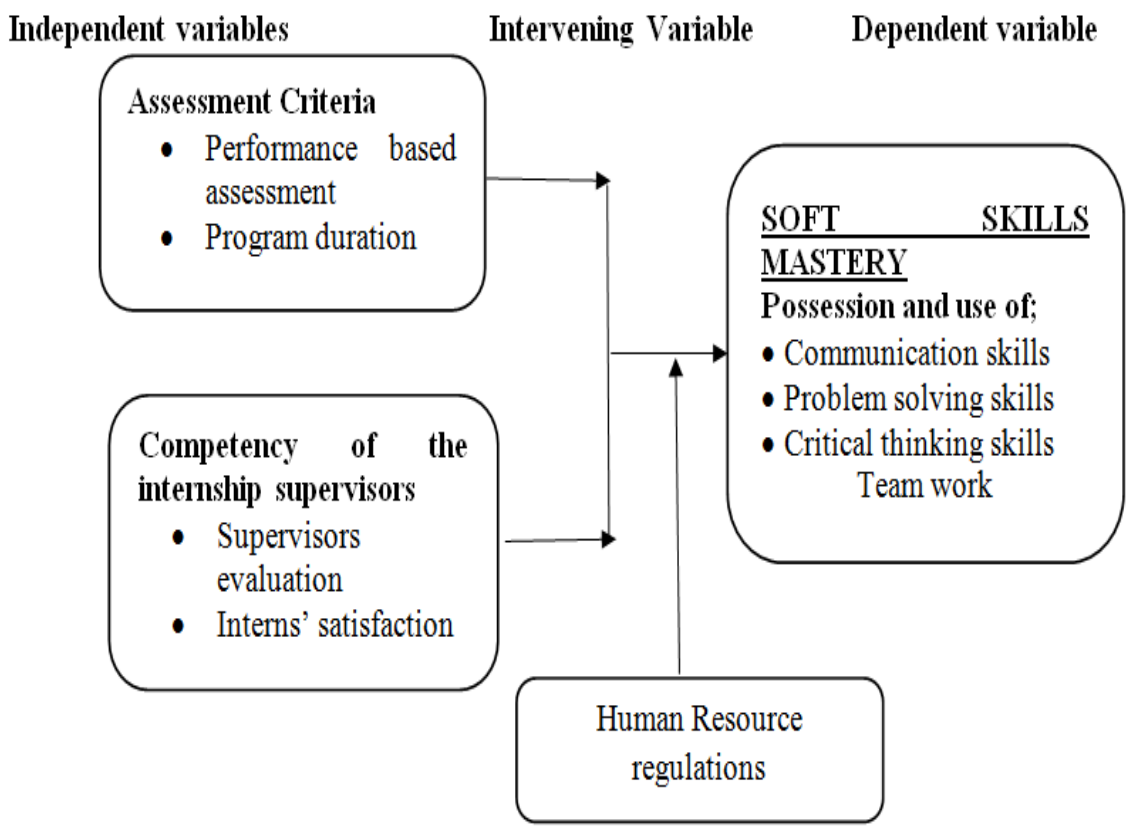

\subsection{Research Gap}

Many researchers have extensively focused on other attributes, however none of these studies address effect of selected internship factors on mastery of soft skills. This study therefore sought to close this gap by focusing on assessing the effect of selectedinternship factors on soft skills mastery among the interns, evidence from Nakuru County Government.

\section{METHODOLOGY}

\subsection{Research Design}

Descriptive survey research design was used. This design was chosen to helpevaluate effect of selected internship factors on mastery of soft skills among interns in Nakuru County Government. This design is associated with studies where pertinent data are collected at a single point in time to address study objectives and other aspects in interest (Nicholson, 2011). The design is appropriate as it describes the situation at a particular point in time. The choice of this design was further supported by the fact that it can be both descriptive and analytical. The study measured the soft skills mastery of the interns before they joined the program and the point they will be at that time (which in this study was above two months into the internship program). This was relevant to evaluate effect of selected internship factors on mastery of soft skills

\subsection{Sampling Procedure and Sample size}

The study population of 1300 interns is significantly large a fact that necessitated sampling in order to have a feasible unit of analysis (Kothari, 2004). The researcher employed stratified random sampling technique since. Nakuru County has 11sub-counties (strata) the sample was distributed using this technique and respondents were selected from each sub-county using simple random technique.

\subsection{Sampling Size Determination}

A sample size is a part of the population chosen for a survey or experiment. Selecting the sample size for a study requires compromise between balancing the need for statistical power, economy and timeliness(Ahmad \& Halim2017). A sample size was calculated at $95 \%$ confidence interval to ensure the representation of all sub-counties. The sample size was calculated using a formula proposed by Nassiuma (2000).

$$
n=\frac{N c^{2}}{c^{2}+(N-1) e^{2}}
$$

Where $\mathrm{n}$ represents sample size

$\mathbf{N}$ represents study population (1300)

C represents coefficient of variation 21\%-30\%)

e represents error margin (0.02-0.05) the researcher will use a coefficient variation of 0.21 and a standard error of 0.02 .

1

The researcher employed stratified random sampling technique and the respondents were selected from each sub-county using simple random technique. The sample size from each sub-county was calculated using Neyman allocation formulae;

$\mathrm{n}_{\mathrm{h}}=\left(\frac{N h}{N}\right) n$ Where $\mathrm{h}$ is the stratum, $\mathrm{n}_{\mathrm{h}}$ is the sample for stratum, $n$ is the total sample, $N_{h}$ is the population for stratum 
Evaluation of Selected Internship Factorson Mastery of Soft Skills among Interns: Evidence from Nakuru County Government, Kenya

$\mathrm{h}$ and $\mathrm{N}$ is the total population.

Table 1: Sample Size Determination

\begin{tabular}{llc}
\hline Sub-County & Population & Sample- \\
\hline Nakuru East & 150 & 12 \\
Nakuru West & 170 & 13 \\
Nakuru North & 200 & 16 \\
Subukia & 70 & 6 \\
Gilgil & 50 & 4 \\
Naivasha & 120 & 9 \\
Rongai & 90 & 7 \\
Molo & 130 & 10 \\
Njoro & 100 & 8 \\
Kuresoi North & 100 & 8 \\
Kuresoi South & 120 & 9 \\
\hline & & $\mathbf{1 0 2}$ \\
Total & $\mathbf{1 3 0 0}$ & \\
\hline
\end{tabular}

\subsection{Instrumentation}

A self-administered questionnairewas used to collect data on selected internship factors and soft skills mastery. The questionnaire was the most appropriate research tool as it allows the researcher to collect information from a large sample with diverse background; the findings remain confidential, save time and since they are presented in paper format minimize opportunity for bias (Dimmendaal\&Dorrich 2018). Information was collected on various socio-demographic factors such as age, gender, and marital status. In addition, the questionnaire also included specific questions to capture information on the effects of selected factors internship on soft skills mastery among interns and a Likert Scale was employed.

\subsubsection{Pilot Study}

According to Subarimaniam (2019) a pilot study is a small study to test research protocols, data collection instruments, sample requirements strategies and other research techniques in preparation for the main study. A pilot study was conducted to identify potential problem areas and deficiency in the research instruments and protocol prior to implementation during the full study. The study was then pilot tested in Baringo County, Mogotio Sub-County (Appendix V) with the same characteristics, before collecting the data and the necessary corrections made.

\subsection{Validity Testing}

Validity is a measure of the accuracy and truthfulness of scientific findings (Brink, 2006). Content validity is how well an instrument measures a theoretical construct (Hong \& Lee 2015). A valid instrument is one that can facilitate collection of data whose analytical results would be both accurate and truthful. The data collection tool; self-administered questionnaire was subjected to critique and scrutiny by peers and supervisors whose opinion was deemed sufficient. The researcher ensured the face and construct validity of the questionnaire by seeking expert opinion from the researcher's supervisor to ensure that the questions test or measure what they were supposed to measure.

\subsubsection{Reliability Testing}

Reliability relates to the consistency of a measure (Heale, \&Twycross 2015). A participant completing an instrument which measured soft skills mastery had approximately the same responses each time the test was completed. One of the most popular reliability statistics in use today is Cronbach's alpha (Cronbach, 1951). The researcher employed Cronbach's alpha to determine the internal consistency or average correlation of items in a survey instrument to gauge its reliability. An alpha value of 0.929 was obtained. According to Cronbach the internal consistency of the questionnaire is said to be accepted when the reliability is at 0.7 , it is said to be good when it is over 0.8 and is better when it gets closer to 1.0 .

3.6 Data Analysis Method and Presentation of Findings

Data analysis is a process that involves inspecting, cleaning, transforming and modeling the collected data with a view of coming up with useful information, drawing conclusions, and more so enhancing decision making (Burns, 2010). Returned questionnaires were screened to ensure that they were accurately and completely filled. The data collected was analyzed with the aid of Statistical Package for Social Sciences (SPSS) tool. Descriptive statistics was used to obtain frequencies, percentages, means and standard deviation data. Inferential statistics in form of Pearson's product moment correlation, simple and multiple linear regression analysis was used to test the association between selected factors of internship and mastery of soft skills All tests with a p-value of $<0.05$ were considered statistically significant. The results of the analysis were presented in tables and figures. This regression model guided the inferential analysis presented in tables and figures.

$\mathrm{Y}=\beta_{0}+\beta_{1} \mathrm{X}_{1}+\beta_{2} \mathrm{X}_{2}+\varepsilon$

Where:

$\mathrm{Y}=$ represents soft skills mastery

$\beta_{0}=$ represents constant

$\mathrm{X}_{1}=$ represents assessment criteria

$\mathrm{X}_{2}=$ represents competency of the internship supervisors $\mathrm{e}=$ error term (Assumed to be normally distributed)

\section{RESULTS}

\section{A. Response Rate}

In order to establish the effect of selected internship factors 
on soft skills mastery, this study administered 102 questionnaires to interns from Nakuru County Government. After data entry, validation and cleaning, 100 questionnaires were found complete representing a $98 \%$ response rate.

Descriptive Statistics ofAssessment Criteria
According to Mugenda and Mugenda (2003), a 50\% response rate is adequate, $60 \%$ good and above $70 \%$ rated very well. A $98 \%$ responses rate was hence considered adequate for the analysis.

Table 2:Assessment Criteria

\begin{tabular}{|c|c|c|c|c|c|}
\hline & $\begin{array}{l}\text { Strongly } \\
\text { Disagree }\end{array}$ & Disagree & Neutral & Agree & $\begin{array}{l}\text { Strongly } \\
\text { Agree }\end{array}$ \\
\hline $\begin{array}{l}\text { There is relevant and consistent } \\
\text { evaluation method of the internship } \\
\text { (grading system, internship report } \\
\text { and other documents) }\end{array}$ & $1.0 \%$ & $1.0 \%$ & $16.0 \%$ & $48.0 \%$ & $34.0 \%$ \\
\hline $\begin{array}{l}\text { The relation with the } \\
\text { representatives of the faculty within } \\
\text { the internship program is good }\end{array}$ & $0.0 \%$ & $3.0 \%$ & $7.0 \%$ & $51.0 \%$ & $39.0 \%$ \\
\hline $\begin{array}{l}\text { Presence of good evaluation } \\
\text { criteria of the internship. } \\
\text { The internship is capable of } \\
\text { changing my career aspirations and } \\
\text { confirming my career goals }\end{array}$ & $1.0 \%$ & $1.0 \%$ & $16.0 \%$ & $43.0 \%$ & $39.0 \%$ \\
\hline
\end{tabular}

My work would be useful and meaningful for the organization and would be appreciated by colleagues.

The study also assessed perceptions of the interns on assessment criteria. A set five likert questions were asked to the 100 interns and the study established that generally there was relevant and consistent evaluation method of the internship (grading criteria, internship report, performance-based assessment and program duration) as those who agreed with the statement accounted for $82 \%$ (agree and strongly agree). Sixteen percent of the interns were neutral, $1 \%$ disagreed and also only $1 \%$ of the interns totally against the statement. Majority, 90\% (agree and strongly agree) of the interns agreed that the relation with the representatives of the faculty within the internship program was good,7\% were neutral with the statement, $3 \%$ having disagreed and none of them totally disagreed. Also $82 \%$ (agree and strongly agree) pointed out the presence of good evaluation criteria of the internship while $16 \%$ were neutral with the statement those in disagreement accounted for $1 \%$ and also with $1 \%$ strongly disagreeing.

The study also found that $77 \%$ (agreed and strongly agree) of the interns were confident that the internship was capable of changing their career aspirations and confirming their career goals while $8 \%$ were neutral with the statement also $4 \%$ disagreed and only $1 \%$ being in strong disagreement. Majority, 94\% (agreed and strongly agree) also felt that their work would be useful and meaningful for the organization and would be appreciated by colleagues while $4 \%$ being neutral only $2 \%$ disagreed and none strongly disagreed with the statement. According to these findings it is clear that assessment criteria affects soft skills mastery in Nakuru County Government. This study concurred with a study by Washor (2015) which found out that using good internship assessment criteria contributes to student soft skills mastery

\section{Descriptive Statistics of Competence of the Internship Supervisors}


Table 3: Competence of the Internship Supervisors

Information about the expectations related to my
performance within the internship program are well
communicated
There is a clear establishment and
communication of my tasks at the beginning of the
internship by the supervisors

$0.0 \%$

$4.0 \%$

$12.0 \% \quad 44.0 \%$

$40.0 \%$
Strongly

Disagree Neutral Agree Agree

$\begin{array}{lllll}0.0 \% & 1.0 \% & 10.0 \% & 45.0 \% & 44.0 \%\end{array}$

The activities are well organized and distributed

$\begin{array}{lllll}0.0 \% & 4.0 \% & 14.0 \% & 37.0 \% & 45.0 \%\end{array}$

There is a well-organized induction period and a presentation of the organization by the supervisors

$\begin{array}{lllll}1.0 \% & 2.0 \% & 7.0 \% & 46.0 \% & 44.0 \%\end{array}$

There is clear schedule and working program for interns.

$\begin{array}{lllll}1.0 \% & 3.0 \% & 13.0 \% & 49.0 \% & 34.0 \%\end{array}$

[1]

This study sought to establish how competence of period and a presentation of the organization by the supervisors accounted for $90 \%$ (strongly agree and agree), other $7 \%$ were neutral,2\% disagreed with $1 \%$ strongly disagreed with the statement. Majority, $83 \%$ (strongly agree and agree) of the interns also felt that there was clear schedule and working program for interns, however $13 \%$ were neutral with $3 \%$ disagreeing and only $1 \%$ strongly disagreed with the statement.

This implies that Nakuru County has competent internship supervisors who play their role well hence enhancing soft skills mastery among the interns. Hence competence of the internship supervisors affects soft skills mastery. These findings concurred with those of Mgaya (2014) which found out that the competence of the internship supervisors was essential in enhancing technical and soft skills of the students who are the future workforce.

\subsection{Inferential statistic.}

Inferential statistics in form of Pearson's product moment correlation, simple and multiple linear regression analysis was used to test the association between selected factors of internship and mastery of soft skills. All tests with a p-value of $<0.05$ were considered statistically significant. The results of the analysis were presented in tables and figures. 
Table 4: Correlation Analysis

Soft Skills Mastery After Joining the Internship Program

Competence of the Supervisors $\quad$ Pearson Correlation $\quad .062$

$\begin{array}{llc} & \text { Sig. (2-tailed) } & .539 \\ & \mathrm{~N} & 100 \\ \text { Assessment Criteria } & \text { Pearson Correlation } & .207^{*}\end{array}$

Sig. (2-tailed)

.039

$\mathrm{N}$

100

*. Correlation is significant at the 0.05 level (2-tailed).

**. Correlation is significant at the 0.01 level (2-tailed).

This study established that there was an insignificant $(r=0.062, p=0.539)$ correlation between competence of the internship supervisors and soft skills mastery among the interns. There was however a significant $(r=0.207, p=0.039)$ linear relationship between assessment criteria and soft skills mastery after joining the internship program. The findings concur with those of Washor (2015) which found out that using good internship assessment criteria has a significant effect on student soft-skill mastery.

\section{Regression Analysis}

$\mathrm{H}_{0} 1$ : There is no statistically significant effect of competence of the internship Supervisors on soft skills mastery among interns in Nakuru County Government.

This study established that $2.6 \%$ variation in soft skills mastery among interns in Nakuru County Government was explained by competence of the internship supervisors. The model however was not significantly (Sig. >0.05) different from the null model. This study established that adding the controls to the model increased the coefficient of variation by 0.025 . However, this increment was not significant (Sig. F Change $>0.05$ ) thus the controls had no significant effect on how competence of the internship supervisors influenced soft skills mastery in Nakuru County Government. Thus, supporting the research hypothesis that there is no statistically significant effect of competence of the internship supervisors on soft skills mastery in Nakuru County Government. The findings concurred with those (Gloria, Hird, \& Tao 2008).

Table 4.12: Competence of the internship Supervisors Model Summary

Change Statistics

\begin{tabular}{lllll} 
Model & R Square & Adjusted R Square & R Square Change & Sig. F Change \\
\hline 1 & .026 & .013 & .026 & .154 \\
2 & .050 & -.013 & .025 & .742
\end{tabular}

a. Predictors: (Constant), Competence of the internship supervisors (Model 1)

b. Predictors: (Constant),

\subsubsection{Hypothesis 2}

The second hypothesis that guided this study stated that: $\mathrm{H}_{0} 2$ : There is no statistically significant effect of assessment criteria of the internship on soft skills mastery among interns in Nakuru County Government. This study established that $5.4 \%$ variation in soft skills mastery among interns in Nakuru County Government was explained by assessment criteria of the internship program. The model was significantly (Sig. $<0.05$ ) different from the null model and thus a good fit of the data. This study also tested whether the effect of assessment criteria of the internship program on soft skills mastery among interns in Nakuru County Government was moderated by control variables; gender, internship duration, education level and age. This study established that adding the controls to the model increased the coefficient of variation by 0.021 . However, this increment was not significant (Sig. F Change $>0.05$ ) thus the controls had no significant effect on how assessment criteria of the internship influenced soft skills mastery in Nakuru County Government. Thus, the null hypothesis was rejected. Hence the findings concurring with those of (Washor 2015). The findings are presented in Table 4.13 
Table 4.13: Assessment Criteria Model Summary

\begin{tabular}{lllll}
\hline & & & \multicolumn{2}{c}{ Change Statistics } \\
\cline { 3 - 4 } Model & & & & \\
& R Square & Adjusted R Square & R Square Change & Sig. F Change \\
\hline 1 & .054 & .042 & .054 & .036 \\
& .075 & .013 & .021 & .795 \\
\hline
\end{tabular}

a. Predictors: (Constant), Assessment Criteria (Model 1)

b. Predictors: (Constant),

\section{CONCLUSION \& RECOMMENDATION}

\section{A. Conclusion}

Based on the results of the study, it was concluded that the effect competence of internship supervisors was not significant (Sig.>0.05). The study further concluded that a unit change in assessment criteria of the internship significantly (Sig. $<0.05$ ) resulted into 0.772 increment on soft skills mastery as was evidence from the county and also that Nakuru County has competent internship supervisors who play their role well hence enhancing soft skills mastery among the interns. This was evidence from the majority of the interns agreeing and strongly agreeing with the indicators. Hence competence of the internship supervisors affects soft skills mastery.

\section{B. Recommendation}

The study recommends that college institutions should work in collaboration with the organizations or industries where the students are sent for their internship programs to ensure that there is a good assessment criteria put in place, that the interns are well placed as per their professions (person role fitness) and ensure institutional support in order to enhance soft skills mastery among the interns as it was found in Nakuru County Government, Kenya. College institutions should incorporate soft skills mastery in their curriculum as it has great effect in the work environment. It is also recommended that internships should be planned well, supported well and successfully implemented. Organizations or industries should give the interns whatever they may need in order for them to master the important soft skills like teamwork, interpersonal skills, problem solving skills and critical thinking skills that are essential in the work environment.

Human resource managers should enhance mastery of soft skills not only at the entry level but also at any level in the organization. This would help them relate well with others and also successfully perform their work hence achievement of both individual and organizational goals. Institutions may also need to revise the curriculum and how to assess the internship programs. The process may involve significant investment in monitoring of the all process to enhance soft skills mastery. Measures of effectiveness of changes must be developed and used in order to improve assessment criteria of the interns. Internship supervisors are required to develop skills in providing supervision to interns during their internship period in order for them to master soft skills.

\section{REFERENCES}

[1] Adebakin, A. B. (2015). Does internship experience beget academic relevance and employment prospects: an assessment of graduate interns from a Nigerian university.Bulgarian Journal of Science \& Education Policy. 2015, Vol. $9 \quad$ Issue1, p302-316. $15 p$

[2] Agarwal, A., Baratloo, A., Chamandy, N., Ma, Q., Raghunathan, V., So, C. W. K., Application No. 10/089,393.

[3] Ahmad, H., \& Halim, H. (2017). Determining Sample Size for Research Activities. Selangor Business Review, 2(1), 20-34.

[4] Alem, J., \& Boudreau-Larivière, C. (2012). Evaluation of an Internship Assessment Grid for Francophone Physical and Health Education Student Interns. The Canadian Journal for the Scholarship of Teaching and Learning, 3 (1).

[5] Arnold, E. C., \& Boggs, K. U. (2019). Interpersonal Relationships E-Book: Professional Communication Skills for Nurses. Saunders Publishers.

[6] Arat, M. (2014). Acquiring soft skills at university. Journal of Educational and Instructional Studies in The World, 4, 46-51.

[7] Association for Talent Development (ATD). (2012). Association for Talent Development (ATD), 2012. Nairobi.

[8] Balwanz, D. (2012).Youth skills development,informal employment and the enabling enironment in Kenya:Trend and tension, Journal of International Cooperation in Education, 15 (2),69-91.

[9] Barbar, M, \& Bukaliya, R (2014), Organization and Management of Practicum at the Zimbabwe Open University:Issues of Program Effectiveness,Benefits and Challenges,International Journal of Humanities Social Sciences and Education.

[10] Barnwell, S. (2016).Relationship between internships and employment competencies of degreed professionals who completd a college internship.

[11] Beghetto, R. A. (2018). What If? Building Students' Problem-Solving Skills Through Complex Challenges: Building Students' Problem-Solving Skills Through Complex Challenges. ASCD.

[12] Bird, N. Chu, C. \& Oguz, F. (2015). Internship in LIS education: An International Perspective on Experiential Learning. IFLA journal, 41(4), 298-307.

[13] Brink, H. (2006). Fundamentals of Research Methodology for Health Care Professionals. Cape Town: Juta and Company Limited.

[14] Brookhart, S. (2018, April). Appropriate criteria: key to effective rubrics. Frontiers in Education (Vol. 3, p. 22).

[15] Bukaliya, R. (2012). The potential benefits and challenges of internship programmes in an ODL institution: A case for the Zimbabwe Open University. International journal on new trends in education and their implications, 3(1) Vol 118-133.

[16] Burns, N. (2010). Understanding Nursing Research.Building an Evidence Based Practice. Philadelphia: WB Sainders Company.

[17] Cheng, M., Kang,H.,Roebuck,P.,\& Simnett,R.(2009).The employment landscape for accounting graduates and work experience relevance.Australian accountinn review, 19(4),342-351.

[18] Cimatti A. (2016) Definition Development, Assessment of soft skills and their role for the quality of organization and enterprise.

[19] Clokie, T. L., Fourie, E. (2016). Graduate employabilty and communication competence:Are undergraduates taught relevant 
skills?. Business and Professional Communication Quarterly,79 (4), 442-463.

[20] Cronbach, L. (1951). Coefficient alpha and the internal structure of tests. Psychometrika, 16(3), 297-334

[21] Crosbie, R. (200).Learning the soft skills of leadership,Industrial and commercial training, 37(1),45-51.

[22] Cottrell, S. (2017). Critical thinking skills: Effective analysis, argument and reflection. Macmillan International Higher Education.

[23] De Lima, B. J. (2017). Reanimating Dissonance: Culitivating the Antecedents of Barry Hrris'Concept of Movement as Multidimensional Pedagogical Tool for Ontario Post-Secondary Jazz Curricula.

[24] De Vos, A. (2011). Reversible computing: fundamentals, quantum computing, and applications. John Wiley \& Sons.

[25] Dimmendaal, R., \& Dörrich, W. (2018). China: Destination (Un) known?: Utilization of Social Capital for European (family) SMEs regarding Internationalization towards the People's Republic of China.

[26] Dreyfus, S. E., \& Dreyfus, H. L. (1980). A five-stage model of the mental activities involved in directed skill acquisition (No.ORC-80-2).California Univ Berkeley Operations Research Center.

[27] Eldeen, A. I. G., Abumalloh, R. A., George, R.P., \& Aldossary, D. A. (2018),Evaluation of Graduate Students Employabilty from Employer Perspective:Review of the Literature,International Journal of Engineering \& Technology, 7 (2.29),961-966.

[28] Garrison, D. R. (2011). E-Learning in the $21^{\text {st }}$ century: A framework for research and practice, Routledge.

[29] Gloria, A. M., Hird, J. S., \& Tao, K. W. (2008). Self-reported multicultural supervision competence of White predoctoral intern supervisors. Training and Education in Professional Psychology, 2(3), 129

[30] Gibb, A., Haskins, G., \& Robertson, I. (2013). Leading the entrepreneurial university: Meeting the entrepreneurial development needs of higher education institutions. In Universities in change ( $\mathrm{pp}$ 9-45).Springer, New York, NY

[31] Giles Jr, D. E., \& Eyler, J. (1994). The theoretical roorts of service-learning in John Dewey: Toward a theory of service-learning.Michigan Journal of Community Service Learning, 1 (1),7.

[32] Goleman, D. (2011). Leadership: The power of emotional intelligence.Northampon: More than Sound.

[33] Goodchild, M. F., Anselin, L., Appelbaum, R. P., \& Harthorn, B. H. (200). Toward spatially integrated social science. International Regional Science Review, 23 (2) 139-159.

[34] Govindasamy, T. (2001). Successful implementaion of e-learning: Pedagogical considerations.The internet and higher education,4(3-4), 287-299.

[35] Hasbullah, H. (2002). industrial internship programme at universiti teknologipetronas - a collaboration strategy that enhanced students' soft skills in the ever-changing technologY. International Conference on Engineering Education, 1-5.

[36] Heale, R., \& Twycross, A. (2015). Validity and reliability in quantitative studies.Evidence-based nursing, 18(3), 66-67.

[37] Hong, R. \& Lee, S. S. (2015). Further clarifying prospective and inhibitory intolerance of uncertainty: Factorial and construct validity of test scores from the Intolerance of Uncertainty Scale. Psychological assessment, 27(2), 605.

[38] Hoy,W. \& Sweetland, S.R. (2001).Designing better schools: The meaning and measuer of enabling school structures.Educational administration quaterly,37(3),296-321.

[39] Imenda, S. (2014). Is there a conceptual difference between theoretical and conceptual frameworks?. Journal of Social Sciences, 38(2), 185-195.

[40] International Labor Organizations (2019) Soft skills training for Apprenticeship graduates in Tanzania. 18-22 March Arusha.

[41] Ismail, S. (2018). Articulating a space for critical learning with a social justice orientation in an adult education programme. South African Journal of Education, 38(4).

[42] Kamunzyu, E., \& Ndunge, L. (2011)."Challenges facing hospitality industrial attachment as learning experiences in selected institutions in Nairobi-Kenya.

[43] Katula,R. \& Threnhauser, E. (1999). Experiential education in the undergraduate urriculum.Communication Education,48 (3),238-255.

[44] Kolb, A. \& Kolb, D. A. (2005). Learning styles and learning spaces:Enhancing experiential learning in higher education academy of management learning\& education, 4 (2), 193-212.

[45] Kolb, D. (1976).Learning style inventory:technical manual McBer. Boston,MA.

[46] Kothari, C. R. (2004). Research methodology: Methods and techniques. New Age International.
[47] Leblois, A., Damette, O., \&Wolfersberger, J. (2017). What has driven deforestation in developing countries since the 2000s? Evidence from new remote-sensing data. World Development, 92, 82-102.

[48] Meeks, G. (2017). Critical Soft Skills to Achieve Success in the Workplace. Walden Univerty: Walden Dissertations and Doctoral Studies Collection.

[49] Melih, A. (2014). Acquiring soft skills at University. HYPERLINK "https://www.amazon.com/Automotive-Control-Systems-\%25c7akma kci-Paperback/dp/B011SJQUPU?SubscriptionId=AKIAJ2F6RDUSIY CWQMFQ\&tag=desktop-shop-chn-b2c-20\&linkCode $=\mathrm{xm} 2 \& \mathrm{camp}=2$ $025 \&$ creative $=165953 \&$ creativeASIN=B011SJQUPU" It "blank" Automotive Control Systems Ulsoy, A. Galip, Peng, Huei, Çakmakci, MCambridge University Press; 1 edition (1609)

[50] Mayaka, M., \& King, B. (2002). A Quality assessment of education and for Kenya's Tour operating sector. Current Issues in Tourism, 5(2), 112-133

[51] Mgaya, K. (2014). Benefits to host organizations from participating in internship programs in Botswana. Asia-Pacific Journal of Cooperative Education, 15(2), 129-144

[52] Mohammed, I., \& Mohamed, W. A. B. W, (2017). Analysis of the impact of soft skills on Malaysian Technical Institutions.Advanced Science Leters, 23 (9),8984-8987.

[53] Moorthy, K., Munz, Y., Sarker, S. K., \&Darzi, A. (2013). Objective assessment of technical skills in surgery. Bmj, 327(7422), 1032-1037.

[54] Mugenda, O. \& Mugenda AG (2003), Research Methods: quantitative and Qualitative approaches. Nairobi: ACTS.

[55] Muthaura, P. N., Khamis, T., Ahmed, M., \& Hussain, S, R.A. (2015) Perception of the preparedness of medical graduates for internship responsibilities in district hospitals in Kenya:a quality study. BMC medical education, 15(1), 178 .

[56] Nakuru county integrated development plan (2018-2022)

[57] Nassiuma D. (2000). Survey Sampling:Theory and Methods.Nairobi:University of Nairobi press.

[58] Negruta, L.(2015). Aspects of the Internships Importance in Human Resource Training. Procedia - Social and Behavioral Sciences, (Vol $308-314)$.

[59] Ngulube, P., Mathipa, E. R., \& Gumbo, M. T. (2015). Theoretical and conceptual frameworks in the social and management sciences. Addressing research challenges: Making headway in developing researchers, 43-66.

[60] Nhan, N. (2018). Issues in soft skills development for Vietnamese students in current undergraduate programs. TapchíKhoahoc, 15(7), 114.

[61] Nicholson, P. (2011). Occupational Health Services in the UK-Challanges and Opportunities. Occupational Medicine, 147-152.

[62] Nusrat, M. (2018). Soft skills for sustainable employment of Business Graduates of Bangladesh. Bangladesh: Bangladesh University of Professionals.

[63] Pagano, M., \&Gauvreau, K. (2018). Principles of biostatistics. Chapman and Hall/CRC.

[64] Paul, Y. (2011). A Study On Drug Abuse Among Youths and Family Relationship. Hong Kong: University of Hong Kong.

[65] Parks, D. Onwuegbuzie, A. J., \& Cash, S. H. (2001). Development of a measure for predicting learning advancement through coorperative education: Reliability and validity of the PLACE scale journal of Cooperative Education, 36(1).23

[66] Pickering, K. (2018). Navigationg discourses of power through relationships: Aprofessional and technical communication intern negotiates a meaningful identity within a state legislature .Journal of Technical Writing and Communication,48 (4),441-470.

[67] Pop, C. \& Barkhuizen, N. (2013). Exploring the effectiveness of a work-integrated learning programme in contributing towards the employability of graduates:The graduate interns' perspective.The Africa Journal for Work-Based Learning, 1(1),28-38.

[68] Ramlall, S., \& Ramlall, D. (2014). The value of soft-skills in the accounting profession: Perspectives of current accounting students. Advances in Research, 2(11), 645-654.

[69] Ramatchandirane, N., \& Upadhyay, V. (2019) Program verification using hash chains. U.S. Patent Application No. 10/185,595.

[70] Roebuck, P., \&Simnett, R. (2009). The employment landscape for accounting graduates and work experience relevance. Australian accounting review, 19(4), 342-351.

[71] Sanchez Puerta, M. Johansson de Silva, S., \&Rizvi, A. (2018). Kenya: Capturing Skills Requirements and Assessing Skills Gaps in the Modern Economy.

[72] Steffe,L \& Gale,J (1995). Constructivism in Education 159.

[73] Subarimaniam, N. (2019). Reliability analysis of self-efficacy in dealing with legal and ethical issues. Journal of Interdisciplinary Studies in Education, 7(2), 31-37. 
[74] Turner, A. G. (2003). Sampling frames and master samples. United Nations Secretariat Statistics Division.

[75] Van Aken, \&Berends, H. (2018). Problem solving in organizations. Cambridge University Press.

[76] Waiganjo, M. M. \& Waiganjo, M. M. (2018). Relevance of life skills Education in preparing Kenyan Youth for National Development, Journal of African Studies in Educational Management and Leadership Vol: 10,85-103.

[77] Walo,M. (2000).The contribution of internship in developing industrial-relevant managent competencies in tourism and hospitality graduates.

[78] Washor, K. (2015). Bridging the soft-skill gap from education to employment through Internships.

[79] Welsh, J., \& Metcalf, J. (2003). Faculty and administrative support for institutional effectiveness activities: a bridge across the chasm?. The Journal of Higher Education, 74(4), 445-468.

[80] Wen, P. Macdonald, D. R., Reardon, D. A., Cloughesy, T. F., Sorensen, A. G., Galanis, E. \& Tsien, C. (2010). Updated response assessment criteria for high-grade gliomas: response assessment in neuro-oncology working group. J ClinOncol, 28(11), 1963-1972.

[81] Woo, Y., \& Reeves, T. C. (2007).Meaningful interaction in web-based learning:A social Zconstructivist interpretation.The Internet and higher education, 10 (1), 15-25.

[82] Yamane, T. 1967. Statistics, An Introductory Analysis, 2nd Ed., New York: Harper and Row.

[83] Yanawati, R. (2017). The influence of cultural differences on interpersonal communication and the implications towards peer guidance. In Proceeding the International Conference on Education Innovation (Vol. 1, No. 1, pp. 683-686).

[84] Yasssin, S., Hasan, F. A.,W.,\& Amiruddin, N. (2008). Implementation of generic skills in the curriculum.

[85] Yusoff, M., Rahim, A., Baba, A. Ismail, S. \& Pa, M. N. M. (2013). Prevalence and associated factors of stress, anxiety and depression among prospective medical students. Asian journal of psychiatry, $6(2)$, 128-133.

[86] Mohammed, I., \& Mohamed, W. A. B. W, (2017). Analysis of the impact of soft skills on Malaysian Technical Institutions.Advanced Science Leters, 23 (9),8984-8987.

[87] Moorthy, K., Munz, Y., Sarker, S. K., \&Darzi, A. (2013). Objective assessment of technical skills in surgery. Bmj, 327(7422), 1032-1037.

[88] Mugenda, O. \&Mugenda AG (2003), Research Methods: quantitative and Qualitative approaches. Nairobi: ACTS

[89] Muthaura, P. N., Khamis, T., Ahmed, M., \& Hussain, S, R.A. (2015). Perception of the preparedness of medical graduates for internship responsibilities in district hospitals in Kenya:a quality study. $B M C$ medical education, 15(1),178.

[90] Nakuru county integrated development plan (2018-2022)

[91] Nassiuma D. (2000). Survey Sampling:Theory and Methods.Nairobi:University of Nairobi press.

[92] Yamane, T. 1967. Statistics, An Introductory Analysis, 2nd Ed., New York: Harper and Row.

[93] Yanawati, R. (2017). The influence of cultural differences on interpersonal communication and the implications towards peer guidance. In Proceeding the International Conference on Education Innovation (Vol. 1, No. 1, pp. 683-686).

[94] Yasssin, S., Hasan, F. A.,W.,\& Amiruddin, N. (2008). Implementation of generic skills in the curriculum.

[95] Yusoff, M., Rahim, A., Baba, A. Ismail, S. \& Pa, M. N. M. (2013). Prevalence and associated factors of stress, anxiety and depression among prospective medical students. Asian journal of psychiatry, 6(2), 128-133. 